\title{
The Quest for Market Exclusivity in Biotechnology: Navigating the Patent Minefield
}

\author{
Judge David M. Gersten \\ Third District Court of Appeal, Miami, Florida 33175
}

\begin{abstract}
Summary: A patent is a legal device that grants an inventor market exclusivity over a new invention or medication. Market exclusivity can mean tremendous economic rewards for the patent holder because it provides the inventor with a monopoly over the invention for the 20-year patent term. Obtaining a patent and retaining market exclusivity can be a treacherous process, especially in the arena of biotechnology patents. Sci-
\end{abstract}

entific, legal, and practical considerations must be carefully weighed to best protect an inventor's rights. This article explores some common patenting pitfalls as well as emerging issues that are specific to the area of biotechnology patenting. Key Words: Patent, market exclusivity, litigation, intellectual property.

\section{INTRODUCTION}

Patents grant the creators of new inventions exclusive control and possession over those inventions. ${ }^{1}$ This allows the inventor to prevent others from commercially using ideas or inventions without the creator's permission during the life of the patent. ${ }^{2}$ Yet, obtaining a patent and market exclusivity is not rocket science. If it were rocket science, the process would be much simpler.

This article discusses some patenting basics as well as common pitfalls and new developments in the law. We begin with an overview of the patenting process and the importance of market exclusivity. We then discuss the role of government action and judicial determinations in the patenting arena. Finally, we address patent litigation issues including the roles that lawyers and judges play in patent law development.

\section{PATENT BASICS}

The United States Constitution granted Congress the power to protect inventors with patent rights. ${ }^{3}$ Congress first exerted this power by passing the Patent Act of 1790. The current version of the law is the Patent Act of 1952, which has been amended over two dozen times.

Address correspondence and reprint requests to Judge David $\mathrm{M}$ Gersten, Third District Court of Appeal, 2001 SW 117 Avenue, Miami, FL 33175. E-mail: gerstend@ flcourts.org.
The United States Patent and Trademark Office (USPTO) is the federal administrative agency that issues patents for the use and development of inventions. Patents are available for items such as new medications and equipment. They also cover processes, machines, articles of manufacture, and compositions of matter. To be patentable, an invention must be useful, novel, and not obvious to a person with ordinary skills in the relevant discipline. $^{4}$

The process of obtaining a patent begins when an inventor files a patent application in the USPTO. It is important to file a patent application as soon as practicable because the first person to file gains priority over all others who claim rights to the same invention. The application describes the invention, gives examples of how it can be used, and usually includes illustrations like schematic drawings or graphs. Filing swiftly is important, but so is thoroughness. The inventor cannot add new information once he or she has already filed a patent application. ${ }^{5}$

Once an inventor files a patent application with the USPTO, the USPTO then assigns the application to one of its individual patent examiners. This examiner searches U.S. patents based on the inventor's patent application claims. The examiner then issues an "Office Action" indicating whether the USPTO will grant or reject the inventor's request for a patent. Litigation sometimes ensues. Figure 1 illustrates the patent application process. 


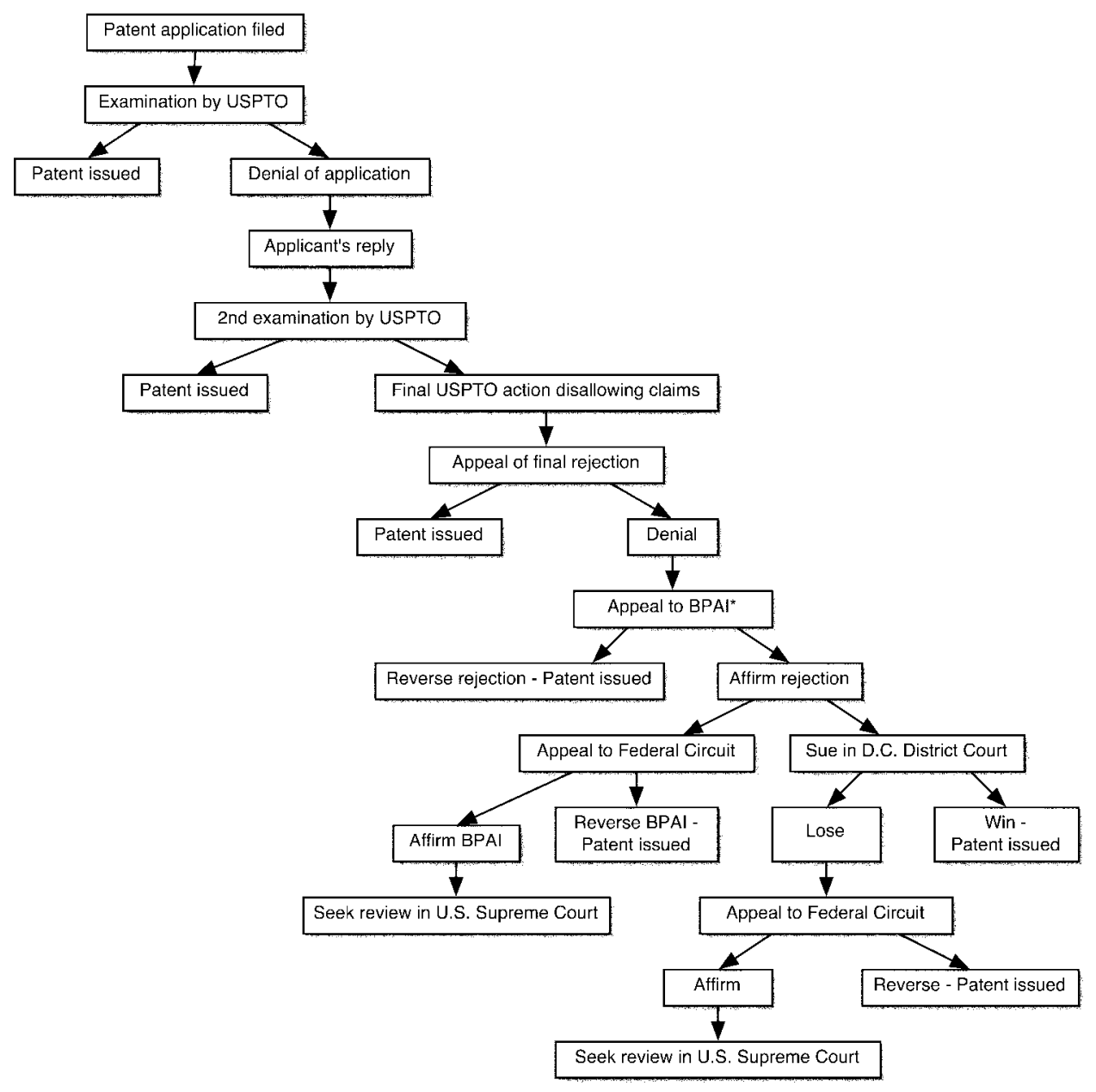

"Board of Patent Appeals and Interferences

FIG. 1. Patent application process flow chart.

\section{MARKET EXCLUSIVITY}

The quest for market exclusivity is the engine that drives patent legislation and litigation. ${ }^{6}$ Market exclusivity describes the crucial period of time, usually 20 years, when an entity enjoys an economic monopoly on its invention. These two decades of market exclusivity can bestow huge economic rewards for any inventor, and are extremely critical to the success of biotechnology companies in both profitability and recuperating invested capital. $^{7}$ Market exclusivity also provides a vital incentive for continued development of new inventions.

Without patent protection, the typical biotech company is unlikely to invest the capital needed to develop innovative medications. ${ }^{8}$ Diminished patent protection will reduce innovative desire to develop new and potentially better drugs and treatments, which in turn could result in the use of more expensive treatments. ${ }^{9}$

Market exclusivity has become even more critical in recent years due to a decline in innovative theories and formulations. ${ }^{10}$ For instance, pharmaceutical innovation has drastically declined and is concurrent with an ex- treme escalation in research costs. ${ }^{11}$ In turn, skyrocketing research costs have resulted in an increased dependence on market exclusivity as a means of maintaining growth and profitability. ${ }^{12}$ An astute understanding of intellectual property (IP) laws and federal regulations is, therefore, vital to the biotech company's ability to successfully obtain and keep patent rights.

\section{GOVERNMENT ACTION IN THE PATENT ARENA}

The federal government formulates patenting policies and enacts the patent laws that govern these policies. Two seemingly contradictory goals have guided the federal government's rule-making: encouraging pioneer companies to continue developing innovative technologies while also making inexpensive generic pharmaceuticals available to consumers. ${ }^{13}$

In 1984, President Ronald Reagan recognized the importance of market exclusivity for new drugs by signing the Drug Price Competition and Patent Term Restoration 
Act of 1984 (Hatch-Waxman Act). ${ }^{14}$ The Hatch-Waxman Act expanded the Federal Food, Drug, and Cosmetic Act to include the universe of drugs for which the Food and Drug Administration (FDA) accepts Abbreviated New Drug Applications (ANDAs). The Hatch-Waxman Act also provided for new drug product exclusivity. The legislature's intent behind these reforms was to encourage research and development, while at the same time, expedite the entry of generic drugs into the market. $^{15}$

The Hatch-Waxman Act also sought to maximize incentives for innovator companies so they would continue investing in research and development for new drugs. To balance the benefits provided to generic companies, the Act established a 5-year exclusivity period for new molecular entities. Even more significantly, the Act provided patent term extensions for brand-name innovator companies in specified circumstances. ${ }^{16}$ This allowed pioneer companies to gain an extended patent term for patents claiming a drug product, or its method of use or manufacture. This statutory patent term restoration made up for some of the time lost by pioneer companies during the FDA regulatory review process.

Both FDA rule reforms and Hatch-Waxman amendments have proven successful in closing several patenting loopholes, but the ever-growing competition among generic and pioneer drug companies will undoubtedly require further refinement through regulatory, legislative, and judicial action. Of these three, the judicial venue will prove to be the final frontier in resolving patent protection conflicts between brand name and generic drug companies.

\section{JUDICIAL DETERMINATIONS}

Obtaining and keeping market exclusivity has become an increasingly uncertain task due to inconsistencies in court opinions. Biotechnology evolves rapidly while the courts struggle to apply patent law consistently in a constantly shifting landscape. ${ }^{17}$

The most recent major legal development has resolved a struggle between companies holding patents to inventions, and those who wish to use the inventions to conduct further research. The courts have sided with innovation, making it easier to conduct experiments using another company's patented inventions. Such use does not constitute infringement so long as there is a reasonable basis to believe that the research will produce the types of information relevant to obtaining FDA approval for a new drug or treatment. ${ }^{18}$ Although this development is welcome news to researchers, it means that patent-holding companies lose out on licensing fees and business leveraging power for other companies' use of their inventions in research.

Another challenge that courts have faced is deciding whether an invention is patentable at all. "[I]t remains axiomatic that principles, laws of nature, mental processes, intellectual concepts, ideas, natural phenomena, and mathematical formulae are not patentable, although the line between patentable inventions and principles of nature has become more difficult to draw." ${ }^{19}$ Distinguishing between which inventions fall under the umbrella of patent protection proves increasingly difficult as technology blurs the distinction between natural fact and scientific discovery. ${ }^{20}$ Courts have also addressed whether naturally occurring but recently discovered chemical compounds, such as DNA, are patentable inventions or unpatentable natural phenomena. ${ }^{21}$

For instance, courts have had to decide whether and how patents protect metabolites formed within a patient's body after ingesting a patented drug. A drug often converts into another chemical compound, or metabolite, when a patient ingests it. ${ }^{22}$ The courts have long recognized that a metabolite has the potential to receive a patent. However, the manner in which a drug company frames its patent claims, and the way that the court defines the claimed terms, can determine whether the metabolite receives protection from infringement.

An "optimal strategy" is for an inventor to "patent both the pre-ingested form of the drug and its new physical forms or metabolites, as formed in the body ('in vivo')." ${ }^{23}$ This presupposes that the inventor has invested the resources to discover the drug's action in the body before filing its patent application. It is important to "include claims to pharmaceutical compositions, preparations, doses or dosage forms and not simply rely on simple 'compound' claims." 23

Novartis experienced a devastating outcome based on the court's interpretation of its patent claim language. The company's failure to carefully draft its patent claim cost Novartis market exclusivity of its formulation for administering cyclosporin.

Novartis dissolved cyclosporin, which is not very soluble in water, in a solvent and added large amounts of water. Novartis described this as a "hydrosol" in its claim for patent protection. A competing company, Eon, manufactured capsules containing cyclosporin dissolved in a small amount of ethanol, absent any water. Novartis sued for indirect patent infringement, arguing that Eon's capsules formed the patented "hydrosol" when patients ingested the capsules and the drug mixed with water in their stomachs. The Federal Circuit found that Eon's capsules did not infringe Novartis' patent. The court construed "hydrosol" to mean a dispersion formed outside of the body, and not inside a patient's stomach. ${ }^{25}$

Polymorphism has also presented a scientifically challenging issue for biotech companies, and a legally challenging one for the courts. Polymorphism is the concept of a molecule assuming multiple crystal structures. ${ }^{26}$ Polymorphism can have a "profound effect on the shelf 
life, solubility, formulation properties, and processing properties of a drug." ${ }^{27}$ One polymorph of a drug can be more effective than another, easier or more difficult to manufacture, or even dangerous. ${ }^{27}$

Polymorphs raise patenting considerations because a company may choose to patent either the molecule's structure, one of its specific crystallized states, or both. Some companies have used polymorphism to their advantage. By patenting a polymorph after the original drug has been patented, a company can extend its period of market exclusivity. ${ }^{29}$ However, polymorphism can also present a patenting pitfall. Consider if a competitor discovers an unpatented polymorph that is easy to manufacture and is as effective as the original drug. Because it is a polymorph, its production will not infringe on the inventor's patent. Early research to discover a drug's polymorphs and their properties is therefore crucial.

An additional issue has recently emerged involving enantiomeric drugs derived from racemate pharmaceuticals for which a company already holds a patent. ${ }^{30}$ Many drugs are compounds made up of different mixtures of stereoisomers, and such mixtures can consist of either enantiomers or isomers. A "racemate" or "racemic mixture" is a compound consisting of an equal mixture of pairs of enantiomers. ${ }^{30}$

Many companies holding a patent nearing expiration for a racemic drug choose to remarket the drug as a single enantiomer under a different patent. This process of "racemic switching," allows drug companies to apply for FDA approval of the enantiomer, before the expiration of the racemic patent, while maintaining market exclusivity for the drug as a whole. Due to the fact that enantiomer pharmaceutical sales reached $\$ 160$ billion in 2002, racemic switching has become another valuable topic of discussion in the biotech patent arena. ${ }^{32}$

Murky areas of science, like predicting polymorphism, detecting metabolites, and identifying compounded enantiomers, lead to inconsistent patent claim construction by the courts. Together, the uncertainty in science and the law have created some treacherous ground on which biotech companies must tread with care. Hopefully, as technologies develop further, the courts can reach a consensus on how to approach the patenting issues these new technologies present.

\section{LITIGATION STRATEGIES}

Thorough research and careful patent planning are crucial because they can help to avoid costly, lengthy, and unpredictable patent litigation. Patent litigation, especially in the context of biotechnology, involves complex scientific and legal issues. It is difficult to predict the outcome of such litigation because scientists, patent lawyers, judges, and juries all bring different experiences to the table.
An important aspect of patent litigation is avoiding it in the first place. Selecting a competent patent lawyer who has a hard science background in the relevant field is crucial. There are two basic choices when selecting a firm to handle your IP issues: a large multifaceted firm that has an IP component to its practice, or a smaller "boutique" firm that only handles IP cases.

When selecting a firm some considerations include: the number of lawyers that compose the IP practice, whether the lawyers have hard science degrees and technical backgrounds, and whether they have obtained special licensing by the patent bar. The importance of your lawyer's technical and hard science experience should not be underestimated. ${ }^{33}$ An excellent corporate or litigation attorney cannot be effective in a patent case if he or she does not fully understand the technical issues. Your lawyer should also be mindful of practical considerations and understand the balance between protecting patent rights and keeping legal fees reasonable.

Patent litigation requires the careful analysis and preparation of complex technical and legal issues. ${ }^{34} \mathrm{~A}$ company contemplating a suit must balance the costs and risks of litigation against the business advantage they seek to obtain. A patent infringement lawsuit initiated by the biotech company/patent owner seeks to secure what the patent owner believes to be a protected position. ${ }^{35}$ Any party whose interests face jeopardy of patent infringement can also bring suit for the purpose of seeking a declaration concerning the patent's validity and scope. ${ }^{36}$ Figure 2 shows a patent infringement flow chart.

The stakes are extremely high for attempting to obtain, retain, or invalidate a patent. Unlike the typical tort claimant, the patent owner who initiates litigation potentially endangers the very patent upon which the basis for the legal claim rests. Studies indicate that complaining patent owners have lost in a significant number of the cases based upon judicial determinations that the patent is invalid. ${ }^{37}$ The expenses and risks involved require a

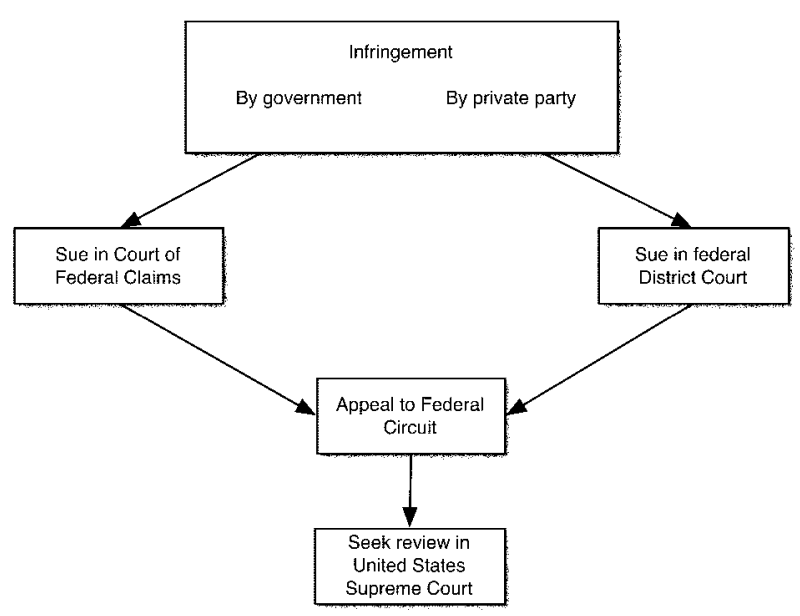

FIG. 2. Patent infringement flow chart. 
company to weigh the possible advantages gained from compromising an infringement controversy with the disadvantages of filing suit.

A company might seek an alternative course to litigation, such as agreeing to issue a license under the patent. ${ }^{38}$ The company can thus derive some royalties from limited competition, rather than chance a legal decision that could result in complete invalidation of the patent and unlimited competition.

It is important for biotech companies as patent owners to precisely define the goals sought by litigation and the potential ramifications. Before initiating suit, a company must thoroughly review and analyze the strength of the patent and its enforcement capabilities to gain a clear understanding of their available options. Both legal and business considerations determine the practical advantages of filing a patent infringement action.

For example, there is no way to predict the outcome of a suit once it goes to court. At a bench trial, a judge makes the legal rulings and findings of fact, and issues the verdict. The trial judge that hears the case may or may not have any expertise in patent law and is unlikely to have a background in the relevant technical or scientific discipline. In a jury trial, the judge makes legal rulings and the jury makes findings of fact before reaching a verdict. It is a virtual certainty that the jurors will not have any experience in patent law, and it is unlikely that they will have any relevant scientific or technical background. ${ }^{39}$ Considering that patent cases involve complex legal and technical issues, and fall under the scrutiny of individuals with potentially no expertise in either area, the appellate process is crucial to obtaining consistent and correct results. Appellate courts have the final say.

The Court of Appeals for the Federal Circuit is an appellate court that specializes in patenting issues. The court has "nationwide jurisdiction to hear appeals in specialized cases such as those involving patent laws." 40 The President nominates judges who must then receive confirmation by the Senate to gain appointment to a term for life or good behavior. There are no specific qualifications for becoming a federal judge, but Congress and the President select highly skilled lawyers from diverse backgrounds including expertise in patent law. For instance, the twelve judges presently composing the Federal Circuit include two chemists, a law school patent professor, and two former USPTO patent examiners. ${ }^{41}$ The Federal Circuit court does not exclusively hear patent cases. It also addresses claims in diverse areas including government contract disputes and veterans' appeals. Even this group of highly skilled jurists has not reached consistent opinions dealing with the sticky issues that biotechnology patents have recently raised. ${ }^{42}$

For instance, there are presently two separate lines of cases promoting different methods for patent claim con- struction. The first line of case law indicates that evidence intrinsic to the patent itself, particularly inventor's written description of the invention, is the primary source for determining the claim meaning. Under this approach, evidence extrinsic to the patent is useful only insofar as it "can shed useful light on the relevant art-and thus better allow a court to place itself in the shoes of a person of ordinary skill in the art" reading the claims alongside the rest of the specification. ${ }^{43}$

The Federal Circuit has suggested a second approach in some of its recent opinions. Under this other view, extrinsic sources such as dictionary definitions take precedence over the intrinsic record. That is, "the intrinsic record, except for the claims, are consulted only after the ordinary and customary meaning of claim terms to persons skilled in the pertinent art is determined." 44 The court might define terms contained in the patent in a way contrary to the intention or foresight of the patent applicant.

The question, then, is "whether the intrinsic evidence takes priority in our construction of the claim term, or if instead the ordinary meaning of the term, as determined from sources such as treatises and dictionaries, controls our construction in the absence of intrinsic evidence of clear lexicography or disavowal." 45

The Federal Circuit seeks to finally resolve this issue in an eagerly anticipated opinion. ${ }^{46}$ A clear and decisive opinion resolving the law of claim construction would receive a warm welcome from the legal community. However, the likelihood of one cohesive opinion is uncertain, especially considering the long history of divergent case law.

One example of the divergent case law is Metabolite Labs., Inc. v. Lab. Corp. of Am. Holdings. ${ }^{47}$ This recent suit illustrates how trial judges, juries, and various appellate courts interact and make litigation complex and unpredictable.

Metabolite sued LabCorp for using Metabolite's patent while testing for vitamin B deficiencies. In this jury trial, the trial judge handled legal issues, and the jury had to determine whether LabCorp had willfully infringed Metabolite's patent. The jury, finding willful patent infringement, assessed \$3.6 million in damages against LabCorp for breach of contract and another $\$ 1$ million for patent infringement.

The Federal Circuit appellate court determined that the trial court had correctly defined the patent's terms. The court also approved the jury's finding that LabCorp had willfully infringed the patent. ${ }^{48}$ Although the Federal Circuit agreed with the trial court's findings, this did not end the story. Litigation is ongoing. The case is presently on appeal in the United States Supreme Court.

The Supreme Court is focusing on a separate issue from the Federal Circuit. Instead of asking whether LabCorp violated Metabolite's patent, it will be entertaining 
argument as to whether Metabolite's patent held any validity before the outset of the case. The Court is concerned that the method of measuring vitamin B deficiency is, in actuality, only a natural phenomenon, and therefore, ineligible for patent protection. ${ }^{49}$

It is possible that Congress may decide to grant potential litigants some relief from the often overbearing and, many times, discouraging or prohibitive expense of litigation. The National Academy of Sciences (NAS) recently suggested a less costly and time-consuming alternative to traditional claim re-examination and litigation. $^{50}$

NAS proposes that, within a short time after the USPTO grants a patent, a third party should be able to challenge the USPTO's decision. This review process would consist of an administrative proceeding that could provide a quick and relatively cheap resolution of the third party's challenge. This system would not only expedite third party claims in a cost-effective manner, but it would also swiftly grant the patent-holder certainty that its patent is valid. If and until Congress enacts such a system, traditional litigation will, unfortunately, remain so costly that it "renders many patents de facto unenforceable." 51 Inventors would wholeheartedly embrace congressional relief from the presently unpredictable, lengthy, and expensive patent litigation system.

\section{CONCLUSIONS}

To obtain market exclusivity, biotech companies need to be aware of how science and patent law interact. Scientific issues affecting patentability, competent legal counsel, and inconsistencies in the way courts apply and interpret biotechnology patent law can all affect a company's ability to obtain, and retain, market exclusivity. Therefore, judicial developments will continue to define the scope of patent protection and guide the future of drug development.

Acknowledgments: Judge David M. Gersten serves as a judge in the State of Florida at the Third District Court of Appeal. Judge Gersten wishes to thank Michelle C. Dunaj and Erin Kinney, Research Assistants, for their aid in researching and editing this article.

\section{REFERENCES}

1. 35 U.S.C.A. $\S ~ 101-103$ (2005).

2. 35 U.S.C.A. $\$ 271(2005)$.

3. U.S. Const. art. I, § 8, cl. 8 (2005).

4. A "useful" item is capable of achieving some identifiable benefit. Juicy Whip, Inc. v. Orange Bang, Inc., 185 F. 3d 1364, 1366 (Fed. Cir. 1999). Novelty is determined by comparing the invention with "prior art." Graham v. John Deere Co. of Kan. City, 383 U.S. 1, 15 (1966); 35 U.S.C.A. $\S ~ 102(a)-(e), 103$ (2005).

5. 35 U.S.C.A. $\S 113$ (2005).

6. Of the patent system's twin purposes, encouraging new inventions and adding knowledge to the public domain, the economic justification is probably the most important rationale. Note, The Dis- closure Function of the Patent System (or Lack Thereof), 118 Harv. L.R. 2007, 2008 (2005).

7. For instance, pharmaceutical companies have a disadvantage compared to other inventors seeking patent protection. A new drug's patent term is forty percent shorter than the effective term for other patented products. PhRMA. Pharmaceutical Industry Profile 2004.

8. It can take many years for a potential new drug to advance from a research idea to a drug approved by the FDA, and can cost more than $\$ 800$ million dollars. PhRMA. Pharmaceutical Industry Profile 2004. There is only a thirty percent chance that an approved drug will produce revenues that match or exceed average research and development costs.

9. There is a $\$ 4.44$ savings on hospital spending for each additional dollar spent on new medicines. PhRMA. Pharmaceutical Industry Profile 2004.

10. The drug industry launched twenty-four new drugs in 2001, which is half the number of new drugs launched in 1996. Jones \& Lunn, "Pharmaceutical Market Exclusivity: Patent and Regulatory Strategies," 21 No. 1 ACCA Docket 81 (2003).

11. Pharmaceutical companies' costs have tripled in the past ten years to $\$ 33$ billion for research and development of new drugs. PhRMA. Pharmaceutical Industry Profile 2004.

12. PhRMA. Pharmaceutical Industry Profile 2004 (noting that "the industry is currently caught between traditional strategies for developing drugs that seem tapped out and new genomics-based approaches that have yet to realize their full potential").

13. H.R. Rpt. 98-857(I), (June 21, 1984) (reprinted in 1984 U.S. C.C.A.N. 2647).

14. 21 U.S.C.A. $\$ \S 301-397$ (2005).

15. Since the Hatch-Waxman Act's enactment, the generic share of the pharmaceutical market soared from less than twenty percent to nearly fifty percent. Generic drug entry prior to patent expiration: an FTC study, Federal Trade Commission (July 30, 2002).

16. 35 U.S.C.A. § 156 (2005).

17. Software developers, too, are experiencing patenting challenges because their field involves rapidly developing technology. Everett, C. Software Terminology: How to Describe a Software Invention in a United States Patent Application. 29 Nova L.R. 693 (Spring 2005).

18. Merck KGAA v. Integra Lifesciences I, Ltd., 125 S.Ct. 2372 (2005).

19. Merrill S, Levin R, Myers M. A patent system for the 21 st century, pp. 144-145. Washington, D.C.: The National Academic Press, 2004.

20. For instance, computer engineers have applied algorithms that bioinformatics researchers developed to study DNA genomes to reverse-engineer proprietary computer software. O'Brien, D. Genome Model Applied to Software. Wired News. Available at http:// wired-vig.wired.com/news/infostructure/0,1377,65191,00.html. Accessed April 22, 2005.

21. Schering Corp. v. Amgen Inc., 18 F.Supp. 2d 372 (D.Del. 1998.) (upholding patent for isolated DNA sequences and recombinant DNA methods for producing interferon protein, but noting that proteins having the same action are natural phenomena).

22. This means that "a person may infringe a claim to a metabolite if the person ingests a compound that metabolizes to form the metabolite." Schering Corp. v. Geneva Pharm., Inc., 339 F. 3d 1373, 1380 (Fed. Cir. 2003). In such a case, the patient is directly infringing the patent, and the company holding the patent can sue the company that manufactured the compound ingested by the patient for indirect infringement.

23. Woessner, W. Claiming Metabolites: Federal Circuit Poses New Challenges to Patent Applicants. Schwegman Lundberg Woessner Kluth IP Resource Center. Available at http://www.slwk.com/CM/ Articles/Articles112.asp. Accessed May 11, 2005.

24. Deleted in proof.

25. Novartis Pharms. Corp. v. Eon Labs Mfg., Inc., 363 F. 3d 1306 (Fed. Cir. 2004).

26. For instance, pharmaceutical chemist Lian Yu manipulated the organic compound known as "ROY" into six different polymorphs, including red needles, orange plates, and yellow prisms. Goho, A. Tricky Business. Science News Online. Vol. 166, No. 8, p. 122, 21 August 2004. Available at http://www.sciencenews.org/articles/ 20040821/bob9.asp. Accessed July 25, 2005. 
27. Knapman, K. Polymorphic predictions. Mod Drug Discov. 3:5354, 57, 2000. Available at http://pubs.acs.org/hotartcl/mdd/00/mar/ knap.html. Accessed July 25, 2005. Predicting polymorphism is important because it can allow researchers to maximize a compound's desired properties and prevent contamination by an unwanted polymorph during the manufacturing process.

28. Deleted in proof.

29. OSI Pharmaceuticals has obtained a patent for a crystalline polymorph of its cancer treatment Tarceva (TM) (erlotinib), which will extend exclusive protection of Tarceva by approximately five years. OSI Pharmaceuticals Announces Issuance of Additional U.S. Patent for Tarceva; Extends Patent Exclusivity. BioSpace Beat. Available at http://www.biospace.com/news_story.cfm?story $\mathrm{ID}=20215120$. Accessed July 25, 2005.

30. "Stereoisomers" "are molecules that are identical in atomic constitution and bonding, but differ in the three-dimensional arrangement of the atoms." "Enantiomeric drugs" are those made up of two mirror-image molecules that have the same chemical composition. U.S. Food and Drug Administration, Center for Drug Evaluation and Research. FDA's Policy Statement for the Development of New Stereoisomeric Drugs. Available at: http://www.fda.gov/ cder/guidance/stereo.htm. Accessed July 25, 2005.

31. Deleted in proof.

32. A. Maureen Rouhi, May 5, 2003, Vol. 81, p. 48, ISSN 0009-2347.

33. Schmidt R. Smart moves on intellectual property. Washington Business Forward. Available at: http://www.bizforward.com/wdc/ issues/2002-03/buzzguide/. Accessed May 10, 2005.

34. Where less than $\$ 1$ million is at risk, the cost of litigation through appeal can reach $\$ 500,000$; where $\$ 1-\$ 25$ million is at risk, that figure rises to $\$ 2,000,000$, and where more than $\$ 25$ million is at risk, average costs are as high as $\$ 3,995,000$. Miller J. Building a better bounty: Litigation-stage rewards for defeating patents. 19 Berkeley Tech. L. J. 667 (2004).

35. A patent holder can bring an infringement action against persons who make, use, or sell the patented invention, those who actively induce patent infringement, and those whose acts constitute contributory infringement. 35 U.S.C.A. § 271 (2005).

36. A potential infringer often seeks a declaration of non-infringement and/or patent invalidity in a declaratory judgment action. The potential infringer must establish that an actual controversy exists by showing the declaratory plaintiff has (1) acted in a way that the patentee asserts infringes the patent, or is preparing to act in such a way; and (2) has a reasonable apprehension of suit for infringe- ment that was created by the patentee. See Spectronics Corp. $v$. H.B. Fuller Co., Inc., 940 F. 2d 631, 634 (Fed. Cir. 1991.); Lang v. Pac. Marine \& Supply Co., 895 F. 2d 761, 764 (Fed. Cir. 1990).

37. Patent and Trademark Office Study of Court Determinations of Patent Validity/Invalidity, 1973-1977, 989 Official Gazette 2 (December 4, 1979); see also Baum, "The Federal Courts and Patent Validity: An Analysis of the Record," 56 J. Pat. Off. Soc'y 758 (1974).

38. SCM Corp. v. Xerox Corp., 645 F. 2d 1195 (2d Cir. 1981).

39. Jurors are randomly selected from voter and/or driver lists. They are disqualified from service only if they, for example, cannot understand English, suffer from a mental or physical infirmity, or have been convicted of a felony without having their rights restored. 28 U.S.C.A. $\S 1861-1878$ (2005).

40. http://www.uscourts.gov/courtsofappeals.html.

41. http://www.fedcir.gov/judgbios.html.

42. See § IV., infra.

43. Vanderlande Indus. Nederland BV v. Int'l Trade Comm'n, 366 F. 3d 1311, 1318 (Fed.Cir. 2004).

44. Astrazeneca AB v. Mutual Pharm. Co., Inc., 384 F. 3d 1333, 1337 (Fed. Cir. 2004).

45. Astrazeneca AB v. Mutual Pharm. Co., Inc., 384 F. 3d at 1338.

46. Phillips v. AWH Corp., 376 F. 3d 1382 (Fed. Cir. 2004).

47. Metabolite Labs., Inc. v. Lab. Corp. of Am. Holdings, 370 F. 3d 1354, 1359 (Fed. Cir. 2004).

48. The jury's task may seem straightforward, however, the Federal Circuit's opinion illustrates its complexity. The court summarized the jury's findings as follows: "physicians order assays and correlate the results of those assays, thereby directly infringing" and "a reasonable jury could find intent to induce infringement because LabCorp's articles state that elevated total homocysteine correlates to cobalamin/folate deficiency." Metabolite Labs., Inc. v. Lab. Corp. of Am. Holdings, 370 F. 3d at 1359.

49. Lab. Corp. of Am. Holdings v. Metabolite Labs., Inc., 125 S.Ct. 1413 (2005).

50. Merrill S, Levin R, Myers M. A patent system for the 21st century. Washington, D.C.: The National Academic Press, 2004.

51. American Intellectual Property Law Association. AIPLA Response to the National Academies Report entitled "A Patent System for the 21st Century." Available at: http://www.aipla.org/Template. $\mathrm{cfm}$ ?Section $=$ By_Topic\&template $=/$ ContentManagement $/$ ContentDisplay.cfm\&ContentID=5544. Accessed May 10, 2005. 